\title{
Tracking the Disseminated Sources for Compositional Work of Music Theorist-Abbot-Composer Johannes Nucius
}

\author{
Magdalena Dostálová / magdalenadostalova@gmail.com \\ Department of Musicology, Faculty of Arts, Masaryk University, Brno, CZ
}

\begin{abstract}
This essay deals with sources for compositional work of music theorist-abbot-composer Johannes Nucius (1556, Görlitz; 25 March 1620, Himmelwitz). Besides a famous theoretical treatise Musices poeticae (1613, Liegnitz) Nucius is also an author of over a hundred sacred vocal compositions and two parodic masses. Even though the motets were published in two printed collections Modulationes sacrae (1591, Prague) and Cantionum sacrarum liber primus and liber secundus (1609, Liegnitz) his compositional output remained slightly neglected. Nevertheless, the tracking and examination of disseminated sources showed, that his music pieces were spread beyond the borders of Upper and Lower Silesia. Given his vivid social relations also outside the monastic life, we should rethink his status of just a music theorist with compositional work of local significance.
\end{abstract}

\section{Key words}

Silesian musical culture, renaissance music, sacred vocal music, Johannes Nucius, dissemination of sources, Georg Wolff von Huldschönau 
Johannes Nucius (1556, Görlitz; 25 March 1620, Himmelwitz) is perceived mainly as a music theorist because of his published treatise Musices poeticae (1613, Neisse/Nysa). His compositional work has been made available thanks to the edition of selected motets from the collection Cantionum sacrarum prepared by Jürgen Kindermann (1968). ${ }^{1}$ For a long time, it was thought that only Nucius' motets were preserved in prints or manuscripts. Older literature was also familiar with the two masses that used to be stored in the Breslau/Wrocław library. Richard Charteris in his book Newly Discovered Music Manuscripts from the Private Collection of Emil Bohn ${ }^{2}$ clarifies the fates of some of these manuscripts from Breslau's churches that were later held in Breslau library and amongs them also those that were considered lost. This interesting impulse of source migration led me to a more detailed investigation and examination of the sources of the compositional work of Johannes Nucius and its dissemination as they reveal new contexts and perspectives regarding his significance as an author.

The life of Johannes Nucius has already been the subject of various published studies. From the earliest efforts to examine the biography of the theorist/composer/abbot we should mention works from the beginning of the $20^{\text {th }}$ century by Reinhold Starke ${ }^{3}$ and Ernst Kirsch, ${ }^{4}$ a later contribution by Joseph Thamm within the musical history of the town Neisse, ${ }^{5}$ and from the most recent researches stand out essays written by Klaus Peter Koch, ${ }^{6}$ Thomas Napp, ${ }^{7}$ and Barbara Eichner. ${ }^{8}$ Given how well researched the topic is, I will only briefly summarize the important milestones of his life to mark the cultural and geographical space of his activities.

Nucius was born in Görlitz/Zgorzelec, where he obtained a humanistic education. As he declares in the preface of Musices poeticae he was taught by Johann Winckler, who was in 1573 appointed cantor in Görlitz and gave Nucius his first musical education. ${ }^{9}$ Quite

1 KINDERMANN, Jürgen. Johannes Nucius (ca 1560-1620). Ausgewählten Motteten. Wiesbaden: Breitkopf \& Härtel, 1968.

2 CHARTERIS, Richard. Newly Discovered Music Manuscripts from the Private Collection of Emil Bohn. Holzgerlingen: American Institute of Musicology, Hänssler Verlag, 1999.

3 STARKE, Reinhold. Johannes Nux (Nucis oder Nucius). Monatshefte für Musik-Geschichte. Leipzig: Breitkopf \& Härtel, 1904, 36. Jahrgang, no. 12, pp. 195-209.

4 KIRSCH, Ernst. Von der Persönlichkeit und dem Stil des schlesischen Zisterzienser-Komponisten Johannes Nucius (ca. 1556-1620). Breslau: Preuss \& Jünger, 1926.

5 THAMM, Jospeh. Musicalische Chronik der Stadt Neisse. Dülmen: Laumannsche Verlagsbuchhandlung, 1974.

6 KOCH, Klaus Peter. Die musikalische Welt des ausgehenden 16. und beginnenden 17. Jahrhunderts. Johannes Nucius - ein Komponist seiner Zeit in Johannes Nucius. Epoka, duchowość, życie i twórczość, red. Remigiusz Pośpiech i Piotr Tarlinski. Opole: Uniwersytet Opolski Wydziat Teologiczny, 2008, pp. 213-240.

7 NAPP, Thomas. Johannes Nucius in Görlitz. Eine Annäherung an die Herkunft des Komponisten und Musiktheoretikers. In POŚPIECH, Remigiusz - TARLINSKI, Piotr (eds.). Johannes Nucius. Epoka, duchowość, życie i twórczość. Opole: Uniwersytet Opolski Wydział Teologiczny, 2008, pp. 241-250.

8 EICHNER, Barbara. A new light on the biography of Johannes Nucius. In GANCARCZYK, Paweł (ed.). Ars musica and its contexts in medieval and early modern culture. Warszawa: Agraf, 2016, pp. 395-408.

9 OTTO, Gottlieb Friedrich. Lexikon der seit dem funfzehenden Jahrhunderte verstorbenen und jeztlebenden Oberlausizischen Schriftsteller und Künstler, Band 3, Görlitz: 1803, s. 528. [online] [cit. 01.27. 2020] Access from: <https://digital.slub-dresden.de/werkansicht/?id=5363\&tx_dlf\%5Bid\%5D=143375\&tx_dlf\%5Bpage\%5D=170>. 
lately (in his thirties) Nucius became a monk in a Cistercian monastery in Rauden/ Rudy. Its abbot, Michael Walther was very supportive of the Prague publication of his first collection of motets entitled Modulationes sacrae. In 1591, after his death, Nucius was elected the abbot in Rauden's subsidiary monastery in Himmelwitz/Jemielnica. During his service there, he published another collection of motets Cantionum sacrarum diversarum vocum liber primus and liber secundus (Liegnitz/Legnica, 1609). Nevertheless, the first book of the motets from the 1609 publication is merely a reprint of the collection published in 1591 and does not provide any new compositions. In his home monastery Johannes Nucius spent the rest of his days until the year 1620 .

\section{The Compositional Output of Johannes Nucius}

Probably the most comprehensive overview of the musical sources for Johannes Nucius' compositional work is provided in the preface to Kindermann's edition Johannes Nucius (ca 1560-1620). Ausgewählten Motteten. ${ }^{10}$ Kindermann's findings had been taken over by other scholars in numerous publications, including the current entries in the Grove $e^{11}$ or $M_{G G}{ }^{12}$ dictionaries, without reviewing the current state of research.

So far, we are aware of 103 motets $^{13}$ ascribed to Johannes Nucius. These are mostly spread across Europe in two printed collections in partbooks. A much smaller number of motets, namely 17 pieces, can be found also in handwritten partbooks, choirbook and tablatures, that come from or later appear in the printed collections. There is one exception: the composition Fit porta Christ is the only known motet that cannot be found in any printed collection. Kindermann's overview of Nucius' music also mentions two masses which the editor considers as having been lost during the second world war. ${ }^{14}$ Thanks to Charteris ${ }^{15}$ re-examination of the manuscripts originally coming from Emil Bohn's collection they were identified in Staatsbibliothek zu Berlin. Because of their unique position within Nucius' preserved work, special attention will be dedicated to them later within this essay.

10 KINDERMANN, 1968, op. cit., pp. VII-IX.

11 BUELOW, George J. Nucius, [Nux, Nucis] Johannes. [online] In The New Grove Dictionary of Music and Musicians. 2001. [cit. 01.27. 2020] Access from: <https://www.oxfordmusiconline.com/grovemusic/view/10.1093/ gmo/9781561592630.001.0001/omo-9781561592630-e-0000020166?rskey=ZeeV7i>.

12 ZYWIETZ, Michael. Nucius, Nux, Nucis, Johannes [online] In Die Musik in Geschichte und Gegenwart Allgemeine Enzyklopädie der Musik. 2016. [cit. 01.27. 2020] Access from: <https://www.mgg-online.com/article?id=m $\operatorname{gg} 09561 \& \mathrm{cv}=1.0 \& \mathrm{rs}=\operatorname{mgg} 09561 \& \mathrm{q}=$ nucius $>$.

13 The motets with more parts are count as one piece.

14 KINDERMANN, 1968, op. cit., p. VII.

15 CHARTERIS, 1999, op. cit., pp. 267-268. 


\section{Two Printed Collections of Motets}

The first of Nucius' collection for five and six voices entitled Modulationes sacrae modis musicis, quinque et sex vocum, recens compositae is closely linked with Bohemia. This publication containing six partbooks was printed by Jiří Nigrin (Georgius Nigrinus) in 1591 in Prag/Praha, ${ }^{16}$ encouraged and supported by Abbot of Rauden Michael Walther. As a gesture of respect and gratitude, Nucius dedicated the collection to him.

It took almost 20 years until his second collection of sacred songs was published. In 1609, two books of motets Cantionum sacrarum diversarum vocum - liber primus and liber secundus were printed. This time, the collections were printed in Liegnitz, not in Prague as the previous print. Considering that the liber primus was just a reprint of the first collection, it is possible that Nucius would have used the services of Jiří Nigrin again, but with his death in 1606, he was forced to find a new publisher. Cantionum sacrarum were dedicated to the archduke of Austria at the time (appointed in 1608), Matthias, who later became King of Bohemia (coronation in 1611, Prague) and Holy Roman Emperor (1612, Frankfurt). ${ }^{17}$

The books of motets consist of pieces composed for 5-6 voices (the first book) and 4-8 voices (the second book). Most of them are in Latin. The only six German compositions differ in that they are typeset in neogothic German script. While setting text to music, Nucius rarely used cantus prius factus as a model melody. The polyphonic manner of creating the melodies in each voice is one of the main features of his motets. Nevertheless, the liber secundus of Cantionum sacrarum shows also some traits of more modern techniques, which accented the importance of lyrics. Besides biblical and liturgical texts, there are motets Cara Theodorum peperit, Wolfius insignem forma, Altera dos thalamis, Quae tibi contigit, ${ }^{18}$ which Nucius composed on special occasions for his friend Georg Wolff von Huldschönau, ${ }^{19}$ a musician, poet, signator and cantor in Neisse/Nysa. Given the type of the collection, Nucius really had to value their friendship highly, as suggested by his incorporation of these celebratory motets.

\begin{tabular}{|l|l|l|l|l|}
\hline Colleciton & Print & Location & RISM No. \\
\hline $\begin{array}{l}\text { Modulationes sacrae modis mu- } \\
\text { sicis, quinque et sex vocum, re- } \\
\text { cens compositae }\end{array}$ & 1591, Prague & Typis Nigrinianis & $\begin{array}{l}\text { PL-Kj, PL-WRu, } \\
\text { PL-Wu, US-Cn }\end{array}$ & N 806 \\
\hline $\begin{array}{l}\text { Cantionum sacrarum diversarum } \\
\text { vocum liber primus, liber secundus }\end{array}$ & 1609 , Liegnitz & $\begin{array}{l}\text { Typis Nicolai } \\
\text { Sartorii }\end{array}$ & $\begin{array}{l}\text { D-Kl, D-Rp, PL-Kj, } \\
\text { PL-WRu, PL-Wu }\end{array}$ & N 807, N 808 \\
\hline
\end{tabular}

Tab. 1 Current dissemination of the printed collections.

16 JAKOUBKOVÁ, Petra. Typografie hudebních tiski̊ Jiř́ho Nigrina. Praha: Univerzita Karlova. Filozofická fakulta. Ústav hudební vědy, 2014. Supervisor doc. PhDr. Petr Daněk, Ph.D.

17 For other compositions (Lambert de Sayve, Christoph Strauss) dedicated to Matthias see LINDELL, Robert. Music at the court of Emperor Matthias. Hudebni věda, 1990, roč. 27, č. 4, pp. 293-298.

18 ZYWIETZ, 2016, op. cit.

19 Georg Wolff von Hulsdchönau was not the only poet in Nucius' circle. There were also Johannes Cyaneus Sylvanus, Marinus Mylius or Salomon Frencelius. For more information about Nucius' relations to Silesian poets see EICHNER, 2016, op. cit. 
According to earlier researches of Robert Eitner ${ }^{20}$ and Julius Adolph Hofmann,,$^{21}$ the dissemination was even more extensive. Partbooks of collection Modulationes sacrae were also held in Bibliotheca Rudolphina in Liegnitz, at Königliches Gymnasium in Brieg/ Brzeg, in the church of St. Cross in Neisse, and in Benedictine monastery in Raigern/ Rajhrad. ${ }^{22}$ Their presence in locations within regions with such a rich cultural history give a sense of the period reception of Nucius' compositions. The current dissemination of the prints is mostly a consequence of the trend of the centralisation of museum collections. One such example is the case of a copy of Cantionum sacrarum liber primus from Krakau/Kraków. ${ }^{23}$ A note on the first sheet stating "in Henrichau S. Ord. cist. bibliothece inscriptus anno 1729" provides evidence of the fact that this collection remained the property of the Cistercian Order in Lower Silesia for decades after its publication, later it became part of private collection of Georg Johann Daniel Poelchau (1773, Kremon; 1836 Berlin). So called Bibliotheca Poelchaviana was after his death in 1841 bought by Staatsbibliothek zu Berlin. From the very frequent marginal comments, inscribed chants and notes, we can assume that this piece of music was extensively in use.

\section{Motets in Manuscripts}

Manuscript copies of Johannes Nucius' compositions are spread in the central European area in three usual types of sources - partbooks (in the table abbreviated as PB), choirbooks (abbreviated as $\mathrm{CHB}$ ) and tablatures (abbreviated as T). The most important collection for these types of Nucius' compositions are Emil Bohn collection from Breslau (nowadays in Staatsbibliothek zu Berlin), ${ }^{24}$ Bibliotheca Rudolphina - Musical Collections of Prince George Rudolf's Liegnitz Library (nowadays in Biblioteka Narodowa in Warsaw and Biblioteka Towarzystwa Przyjaciół Nauk in Liegnitz) ${ }^{25} 26$ and Fenitzer's Library

20 EITNER, Robert. Nucius, Johannes. In Biographisch-bibliographisches Quellen-Lexikon der Musiker und Musikgelehrten der christlichen Zeitrechnung bis zur Mitte des neunzehnten Jahrhunderts, 7. Band. Leipzig: Breikopf \& Härtel, 1902. pp. 217-218.

21 HOFFMANN, Carl Julius Adolf. Die Tonkünstler Schlesiens: ein Beitrag zur Kunstgeschichte Schlesiens vom Jahre 960 bis 1830: enthaltend biographische Notizen über schlesische Komponisten, musikalische Schriftsteller und Pädagogen, Virtuosen, Sänger, Kantoren, Kammermusiker, Instrumentenmacher, so wie über beförderer und Liebhaber der Tonkunst. Breslau: G. P. Aderholz, 1830.

22 Reference in Eitner's Lexikon to a copy of the printed collection kept in Rajhrad's monastery (see EITNER, 1902, op. cit., p. 218) is peculiar. No sign of this information can be found in the preserved card catalogues.

23 Mus. ant. pract. N 255 (PL-Kj).

24 BOHN, Emil. Die musicalischen Handschriften des XVI. und XVII. Jahrhunderts in der Stadtbibliothek zu Breslau. Breslau: Julius Hainauer, 1890.

25 The whole collection Bibliotheca Rudolphina is partly located in four libraries in Warsaw, Breslau, Lublin and Liegnitz. See KOLBUSZEWSKA, Agnizeska. Katalog zbiorów muzycznych legnickiej biblioteki księcia Jerzego Rudolfa Bibliotheca Rudolphina. Legnica: Legnickie Towarzystwo Muzyczne, 1992.

26 BOETTICHER, Wolfgang. Orlando di Lasso und seine Zeit. Kassel: Bärenreiter, 1958, p. 544. 
(nowadays in Bibliothek beim Landeskirchlichen Archiv in Nürnberg). ${ }^{27}$ One manuscript is also held in the Proske Collection in Bischöfliche Zentralbibliothek in Regensburg, ${ }^{28}$ another in the Bártfa musical collection ${ }^{29}$ in Budapest and one in Levoča. ${ }^{30}$

In this respect, two particular names relate to Nucius' music - Friedrich Lindner (1542, Liegnitz - 1597, Nürnberg) and Simon Lyra (1550-1601, Breslau) ${ }^{31}$. They both were cantors and scribes from protestant churches - Lindner in St. Egidien's Church (Nürnberg) and Lyra in the Church of St. Elisabeth (Breslau) - and they both integrated Nucius' composition into choirbooks used in their churches. Another feature shared with Nucius were Lindner's and Lyra's relations towards Lower Silesia. It is this region that might have connected them and facilitated the migration of Nucius' music. The importance of this "social net" is emphasized also by the fact that Lyra was one of the two possible scribes ${ }^{32}$ who captured the parodic masses.

The complete overview of manuscripts is listed below:

\begin{tabular}{|l|l|l|l|l|l|}
\hline Composition & Voices & Type of Source & Shelfmark (library) & Provenance & Remarks \\
\hline Ab oriente venerunt & $5 \mathrm{v}$ & PB & Mus. Ms. 12 (D-B) & $\begin{array}{l}\text { Emil Bohn collec- } \\
\text { tion - Breslau }\end{array}$ & \\
\hline & & CHB & Fen IV 2 (D-Nla) & Fenitzer's library & $\begin{array}{l}\text { scribe } \\
\text { F. Lindner }\end{array}$ \\
\hline Beata Christi passio & $6 \mathrm{v}$ & $\mathrm{T}$ & $\begin{array}{l}\text { Ms. Mus Bártfa 26 } \\
\text { (H-Bn) }\end{array}$ & $\begin{array}{l}\text { Bártfa music col- } \\
\text { lection }\end{array}$ & \\
\hline Dum complerentur & $5 \mathrm{v}$ & CHB & MUS A 1 (SK-Le) & $\begin{array}{l}\text { Levoča music col- } \\
\text { lection }\end{array}$ & \\
\hline Ecce Dominus veniet & $5 \mathrm{v}$ & PB & Mus. Ms. 12 (D-B) & $\begin{array}{l}\text { Emil Bohn collec- } \\
\text { tion - Breslau }\end{array}$ & \\
\hline
\end{tabular}

27 RUBSAMEN, Walter H. The international 'catholic' repertoire of a Lutheran church in Nürnberg 1574-1597. Neuilly-sur-Seine: Société de musique d'autrefois, 1957.

28 HABERKAMP, Gertraut - REUTTER, Jochen - SCHWEISTHAL, Christofer. Thematischer Katalog der Musikhandschriften 2: Sammlung Proske Manuskripte des 18. und 19. Jahrhunderts aus den Signaturen A.R., C, AN. München: Henle, 1989.

29 MURÁNYI, Róbert Árpád. Thematisches Verzeichnis der Musiksammlung von Bartfeld (Bártfa). Deutsche Musik im Osten 2. Bonn: Gudrun Schröder Verlag, 1991.

30 PETÓCZOVÁ, Janka. The Role of Silesia in the development of Musical Culture in the Towns of Spiš/ Zips and Šariš/Scharosch. In The Musical Culture of Silesia before 1742: New Contexts - New Perspectives. Eastern European Studies in Musicology 1. Frankfurt am Main: Peter Lang, 2013, pp. 161-178.

31 POL, Nikolaus. Jahrbücher der Stadt Breslau von N.P. Zum erstenmale aus dessen eigener Handschrift herausgegeben. Breslau: 1824, p. 5. [online] [cit. 01.27. 2020] Access from: <https://books.google.cz/books?id=ollccO8sqeIC\&pg=PP1\&lpg=PP1\&dq=Jahrb\%C3\%BCcher+der+Stadt+Breslau+von+N.P.+Zum+erstenmale+aus+dessen+eigener+Handschrift+herausgegebe\&source=bl\&ots=LugfK1CuOK\&sig=ACfU3U1hHN60CEPoIUpkY1gs3xkjrsSedQ\&hl=cs\&sa=X\&ved=2ahUKEwjZmLz21MXnAhWC2-AKHS3WDW4Q6AEwAXoECAoQAQ\#v=onepage \&q=lyra\&f=false>.

32 It is certain that Lyra is the author of the Mus. Ms. 97 and 98 . The authorship of the Mus. Ms. 99 is unknown, but given the different style of handwriting, it is more likely that there was another scribe. See BOHN, 1890, op. cit. 
Tracking the disseminated sources for compositional work of music theorist-abbot-composer ...

\begin{tabular}{|c|c|c|c|c|c|}
\hline Composition & Voices & Type of Source & Shelfmark (library) & Provenance & Remarks \\
\hline Ecce quam bonum & $6 v$ & PB & $\begin{array}{l}\text { Mus. 2095-2099 } \\
\text { (PL-Wn) }\end{array}$ & \begin{tabular}{|l|} 
Bibliotheca Rudol- \\
phina - Liegnitz \\
(Libr. Mus. 49)
\end{tabular} & \\
\hline $\begin{array}{l}\text { Facta est cum an- } \\
\text { gelo }\end{array}$ & $6 v$ & $\mathrm{CHB}$ & Fen IV 2 (D-Nla) & Fenitzer's library & \begin{tabular}{|l|} 
scribe \\
F. Lindner
\end{tabular} \\
\hline $\begin{array}{l}\text { Factum est silen- } \\
\text { tium }\end{array}$ & $5 v$ & PB & Mus. Ms. 12 (D-B) & $\begin{array}{l}\text { Emil Bohn collec- } \\
\text { tion - Breslau }\end{array}$ & \\
\hline \multirow[t]{2}{*}{ Fit porta Christi } & $4 v$ & $T$ & Mus. Ms. 18 (D-B) & $\begin{array}{l}\text { Emil Bohn collec- } \\
\text { tion - Breslau }\end{array}$ & not in prints \\
\hline & & PB & Mus. Ms. 22 (D-B) & \begin{tabular}{|l|} 
Emil Bohn collec- \\
tion - Breslau \\
\end{tabular} & \\
\hline $\begin{array}{l}\text { Freut euch ihr Aus- } \\
\text { erwehlten }\end{array}$ & $6 v$ & PB & $\begin{array}{l}\text { A. R. } 996-1010 \\
\text { (D-Rp) }\end{array}$ & Proske collection & \\
\hline Hodie completi sunt & $6 v$ & $\mathrm{CHB}$ & Fen IV 2 (D-Nla) & Fenitzer's library & \begin{tabular}{|l} 
scribe \\
F. Lindner
\end{tabular} \\
\hline Hodie in Jordane & $5 v$ & $\mathrm{CHB}$ & Fen IV 2 (D-Nla) & Fenitzer's library & \begin{tabular}{|l|} 
scribe \\
F. Lindner \\
\end{tabular} \\
\hline $\begin{array}{l}\text { Hodie nobis coelo- } \\
\text { rum }\end{array}$ & $5 v$ & $\mathrm{CHB}$ & Fen IV 2 (D-Nla) & Fenitzer's library & \begin{tabular}{|l|} 
scribe \\
F. Lindner \\
\end{tabular} \\
\hline Ite in mundum & $5 v$ & $\mathrm{CHB}$ & Fen IV 2 (D-Nla) & Fenitzer's library & \begin{tabular}{|l|} 
scribe \\
F. Lindner \\
\end{tabular} \\
\hline \multirow[t]{2}{*}{$\begin{array}{l}\text { Missa super Cara } \\
\text { Theodorum }\end{array}$} & $5 v$ & PB & Mus. Ms. 97 (D-B) & $\begin{array}{l}\text { Emil Bohn collec- } \\
\text { tion - Breslau }\end{array}$ & $\begin{array}{l}\text { scribe Simon } \\
\text { Lyra }\end{array}$ \\
\hline & & PB & \begin{tabular}{|l}
$\begin{array}{l}\text { Mus. Ms. 99B } \\
\text { (D-B) }\end{array}$ \\
\end{tabular} & \begin{tabular}{|l|} 
Emil Bohn collec- \\
tion - Breslau \\
\end{tabular} & \\
\hline \multirow[t]{2}{*}{$\begin{array}{l}\text { Missa super Vestiva } \\
\text { i colli }\end{array}$} & $5 v$ & PB & Mus. Ms. 98 (D-B) & $\begin{array}{l}\text { Emil Bohn collec- } \\
\text { tion - Breslau }\end{array}$ & $\begin{array}{l}\text { scribe Simon } \\
\text { Lyra } \\
\end{array}$ \\
\hline & & PB & $\begin{array}{l}\text { Mus. Ms. 99B } \\
\text { (D-B) }\end{array}$ & $\begin{array}{l}\text { Emil Bohn collec- } \\
\text { tion - Breslau }\end{array}$ & \\
\hline \multirow[t]{2}{*}{ Missus est angelus } & $5 v$ & $\mathrm{CHB}$ & Fen IV 2 (D-Nla) & Fenitzer's library & \begin{tabular}{|l|} 
scribe \\
F. Lindner \\
\end{tabular} \\
\hline & & $T$ & Ms. 5232 (PL-Wn) & \begin{tabular}{|l|} 
Bibliotheca Rudol- \\
phina - Liegnitz \\
(Libr. Mus. 101) \\
\end{tabular} & \\
\hline Puer qui natus & $5 v$ & PB & Mus. Ms. 12 (D-B) & \begin{tabular}{|l|} 
Emil Bohn collec- \\
tion - Breslau \\
\end{tabular} & \\
\hline Regina coeli & $6 v$ & PB & Mus. 2083 (PI-Wn) & \begin{tabular}{|l|} 
Bibliotheca Rudol- \\
phina - Liegnitz \\
(Libr. Mus. 111) \\
\end{tabular} & $\begin{array}{l}\text { date before } \\
\text { prints }\end{array}$ \\
\hline Salve festa dies & $5 v$ & $T$ & MUS A 1 (SK-Le) & \begin{tabular}{|l|} 
Levoča music col- \\
lection
\end{tabular} & \\
\hline Salve Regina & $6 v$ & PB & Mus. $2083(\mathrm{PI}-\mathrm{Wn})$ & \begin{tabular}{|l|} 
Bibliotheca Rudol- \\
phina - Liegnitz \\
(Libr. Mus. 111)
\end{tabular} & $\begin{array}{l}\text { date before } \\
\text { prints }\end{array}$ \\
\hline
\end{tabular}

Tab. 2 Current dissemination of manuscripts. 
Noteworthy information comes from the Bibliotheca Rudolphina's Mariale Collection of Georg Wolff von Huldschönau (the earlier shelfmark in Ernst Pfudel's catalogue ${ }^{33}$ was Libr. Ms. 111, nowadays in Warsaw Bibliotheka Narodowa as Mus. 2083). This Mariale is a fascinating collection of 57 motets on texts of almost exclusively Marian antiphones. This source was unfortunately preserved only in the partbook of bassus. ${ }^{34}$ Nucius is represented in this source with two motets - Salve Regina and Regina coeli. The dates added next to the compositions are striking. The Bassus part states: "Anno 1588 die 6. Maij". From this entry, we can consider this as the earliest record of these two Marian songs, which were later published in Cantionum sacrarum. There might have been additional relevant information in the lost partbooks. Ernst Pfudel's catalogue states that an even earlier date was recorded in the alto partbook (November 1587) with a note: "in aedibus Georg. Wolffij faciebat Joan. Nucis." 35 Agnieszka Leszcyńska interprets this statement as an indication that Johannes Nucius composed this piece at Wolfius's home. Hypothetically, it could also refer to the fact that Nucius had inscribed it there himself. That would have made this piece his only preserved autograph.

In addition to the pieces discussed above, Reinhold Starke in his study for Monatsheft für Musikgeschichte $e^{36}$ mentions a motet entitled Christe, qui lux, which should have been part of Liegnitz's collection. Not only is it unfounded that Nucius should have been the composer of such a song, but there also are no hints in Pfudel's catalogue suggesting that this kind of musical material would ever have been part of the collection. The source that led Starke to provide this information remains unclear.

\section{Re-discovered Masses}

In the preface to the Cantionum sacrarum, Nucius states that he was planning to publish masses as soon as health and duties allowed. ${ }^{37}$ Even though he intended to publish them, it never came to this point. Neither are their titles or even numbers known. As they were probably mainly used for practice during the services, rather than for his own presentation as an attempt to obtain a post or win the favour of some nobles or the city council, these pieces remained only in manuscript. Unfortunately, the fire in Himmelwitz of 1617 damaged a part of the village, the monastic building and the church, and most likely also destroyed all the original manuscripts. ${ }^{38}$

33 PFUDEL, Ernst. Die Musik-Handschriften der Königl. Ritter-Akademie zu Liegnitz. Leipzig: Breitkopf \& Härtel, 1886.

34 LESZCYŃSKA, Agnieszka. Remarks on Georg Wolff ab Huldschönau and his Mariale. In PETÖCZOVÁ, Janka (ed.). The Musical Sources of Spiš/Zips and Central Europe. Bratislava: Ústav hudobnej vedy SAV, 2018, pp. $23-32$.

35 "at home of Georg Wolff made by Johannes Nucius".

36 STARKE, 1904, op. cit., p. 204.

37 "ad graviora etiam, Missarum nostrarum videlicet editionem, quamprimum per valetudinem et occupationes livuerit, brevi excitabimur"

38 BUELOW, 2001, op. cit. 
The current location of the copies of the extant manuscript masses is the Staatsibliothek zu Berlin. The two compositions Missa super Vestiva $i$ colli and Missa super Cara Theodorum are preserved in three sources - Mus. Ms. 97, Mus. Ms. 98 and Mus. Ms. 99B. The partbooks come from the end of the 16th century (Mus. Ms. 97 from 1593 and Ms. 98 from 1597). Nos. 97 and 98 have a common scribe Simon Lyra Olsensis; therefore, these might have been in usage in the St. Elisabeth Church in Breslau as mentioned above.

Missa super Cara Theodorum ${ }^{39}$ from Mus. Ms. 97 is included in the collections of 42 masses by different authors ${ }^{40}$ in quarto format, which does not always provide very clear handwriting. The source contains only two parts of the mass - Kyrie and Gloria (Et in terra). As these partbooks were in usage in a Lutheran environment the lack of other parts of the ordinarium is unsurprising. The later manuscript no. 99 of unknown origin does provide the whole mass without the Credo (Kyrie - Gloria (Et in terra) - Sanctus Benedictus - Agnus Dei) but only in two voices (altus, quinta vox).

Even though Nucius usually did not use any cantus prius factus or plainchant for his compositions, in case of the masses, he adopted the compositional trend or technique of parodic masses. The Missa super Vestiva $i$ colli is based on a famous madrigal by Giovanni Pierluigi da Palestrina ${ }^{41}$ and Cara Theodorum ${ }^{42}$ on his own motet composed for the celebration of Georg Wolff's newborn son. Main theme of Palestrina's madrigal is strictly melodically cited in all voices (discantus, altus, tenor 1 and 2, bassus) in Kyrie; Nucius also maintains the original pitch. In case of Missa super Cara Theodorum the model melody is present as well, on top of that even the noticeable syllabic structure is imitated. A feature that Nucius within this parodic mass omitted, was changing the metre from alla breve to triple metre as he did in the motet.

The case of Johannes Nucius is unique. There is no other known historical figure of that time who would combine the service as an abbot in a Cistercian monastery, with quite a narrowly focused compositional work of sacred songs and still vivid connection with other artists (poets, musicians). This unconventional mixture of monastic life and relations to urban culture influenced the dissemination of his musical pieces. Even though Nucius did not need to petition for jobs or get into the favour of city councils to obtain a living, it is remarkable that his work was still known and spread beyond the borders of Upper and Lower Silesia. There must have been some type of social network existing in this area, which helped the wide dissemination of music written by an abbot who dedicated most of his life to a small Silesian monastery. The discovery of such possible relations, only partially outlined in this study, might bring new insights to Nucius' musical biography.

39 Based on the motet Cara Theodorum, that was composed as a celebration of the birth of the son of Georg Wolff von Hulschönau see EITNER, 2016, op. cit., p. 400.

40 Most frequently Orlando di Lasso, Phillipe de Monte, Antonio Scandella, Carl Luython.

41 G. P. da Palestrina: Vestiva i colli. Published in Il desiderio: secondo libro de madrigali a 5 voci de diversi (1566, Venedig/Venezia).

42 Johannes Nucius: Cara Theodorum peperit. Published in Modulationes sacraae (1591, Prague). 


\section{Bibliography}

BOETTICHER, Wolfgang. Orlando di Lasso und seine Zeit. Kassel: Bärenreiter, 1958.

BOHN, Emil. Die musicalischen Handschriften des XVI. und XVII. Jahrhunderts in der Stadtbibliothek zu Breslau. Breslau: Julius Hainauer, 1890.

BUELOW, George J. Nucius, [Nux, Nucis] Johannes. [online] In The New Grove Dictionary of Music and Musicians. 2001. [cit. 01.27. 2020] Access from: <https://www.oxfordmusiconline.com/grovemusic/view/10.1093/gmo/9781561592630.001.0001/omo-9781561592630-e-0000020166?rskey=ZeeV7i>.

EICHNER, Barbara. A new light on the biography of Johannes Nucius. In GANCARCZYK, Paweł (ed.). Ars musica and its contexts in medieval and early modern culture. Warszawa: Agraf, 2016, pp. 395-408.

EITNER, Robert. Nucius, Johannes. In Biographisch-bibliographisches Quellen-Lexikon der Musiker und Musikgelehrten der christlichen Zeitrechnung bis zur Mitte des neunzehnten Jahrhunderts, 7. Band. Leipzig: Breikopf \& Härtel, 1902. pp. 217-218.

HABERKAMP, Gertraut - REUTTER, Jochen - SCHWEISTHAL, Christofer. Thematischer Katalog der Musikhandschriften 2: Sammlung Proske Manuskripte des 18. und 19. Jahrhunderts aus den Signaturen A.R., C, AN. München: Henle, 1989.

HOFFMANN, Carl Julius Adolf. Die Tonkünstler Schlesiens: ein Beitrag zur Kunstgeschichte Schlesiens vom Jahre 960 bis 1830: enthaltend biographische Notizen über schlesische Komponisten, musikalische Schriftsteller und Pädagogen, Virtuosen, Sänger, Kantoren, Kammermusiker, Instrumentenmacher, so wie über beförderer und Liebhaber der Tonkunst. Breslau: G. P. Aderholz, 1830.

CHARTERIS, Richard. Newly Discovered Music Manuscripts from the Private Collection of Emil Bohn. Holzgerlingen: American Institute of Musicology, Hänssler Verlag, 1999.

JAKOUBKOVÁ, Petra. Typografie hudebnich tiski̊ Jiřiho Nigrina. Praha: Univerzita Karlova. Filozofická fakulta. Ústav hudební vědy, 2014. Supervisor doc. PhDr. Petr Daněk, Ph.D.

KOLBUSZEWSKA, Agnizeska. Katalog zbiorów muzycznych legnickiej biblioteki księcia Jerzego Rudolfa Bibliotheca Rudolphina. Legnica: Legnickie Towarzystwo Muzyczne, 1992.

KINDERMANN, Jürgen. Johannes Nucius (ca 1560-1620). Ausgewählten Motteten. Wiesbaden: Breitkopf \& Härtel, 1968.

KIRSCH, Ernst. Von der Persönlichkeit und dem Stil des schlesischen Zisterzienser-Komponisten Johannes Nucius (ca. 1556-1620). Breslau: Preuss \& Jünger, 1926.

LESZCYŃSKA, Agnieszka. Remarks on Georg Wolff ab Huldschönau and his Mariale. In PETÖCZOVÁ, Janka (ed.). The Musical Sources of Spiš/Zips and Central Europe. Bratislava: Ústav hudobnej vedy SAV, 2018, pp. 23-32.

LINDELL, Robert. Music at the court of Emperor Matthias. Hudebni věda, 1990, roč. 27, č. 4, pp. 293-298.

MURÁNYI, Róbert Árpád. Thematisches Verzeichnis der Musiksammlung von Bartfeld (Bártfa). Deutsche Musik im Osten 2. Bonn: Gudrun Schröder Verlag, 1991.

NAPP, Thomas. Johannes Nucius in Görlitz. Eine Annäherung an die Herkunft des Komponisten und Musiktheoretikers. In POŚPIECH, Remigiusz - TARLINSKI, Piotr (eds.). Johannes Nucius. Epoka, duchowość, życie i twórczość. Opole: Uniwersytet Opolski Wydziat Teologiczny, 2008, pp. 241-250.

OTTO, Gottlieb Friedrich. Lexikon der seit dem funfzehenden Jahrhunderte verstorbenen und jeztlebenden Oberlausizischen Schriftsteller und Künstler, Band 3, Görlitz: 1803, s. 528. [online] [cit. 01.27. 2020] Access from: <https://digital.slub-dresden.de/werkansicht/?id=5363\&tx_ dlf $\% 5 \mathrm{Bid} \% 5 \mathrm{D}=143375 \&$ tx_dlf $\% 5 \mathrm{~B}$ page $\% 5 \mathrm{D}=170>$. 
PETŐCZOVÁ, Janka. The Role of Silesia in the development of Musical Culture in the Towns of Spiš/Zips and Šariš/Scharosch. In The Musical Culture of Silesia before 1742: New Contexts - New Perspectives. Eastern European Studies in Musicology 1. Frankfurt am Main: Peter Lang, 2013, pp. 161-178.

PFUDEL, Ernst. Die Musik-Handschriften der Königl. Ritter-Akademie zu Liegnitz. Leipzig: Breitkopf \& Härtel 1886.

POL, Nikolaus. Jahrbücher der Stadt Breslau von N.P. Zum erstenmale aus dessen eigener Handschrift herausgegeben. Breslau: 1824, p. 5. [online] [cit. 01.27. 2020] Access from: 〈https:// books.google.cz/books?id=ollccO8sqeIC\&pg=PP1\&lpg=PP1\&dq=Jahrb\%C3\%BCcher+der+Stadt+Breslau+von+N.P.+Zum+erstenmale+aus+dessen+eigener+Handschrift+herausgegebe\&source=bl\&ots=LugfK1CuOK\&sig=ACfU3U1hHN60CEPoIUpkY1gs3xkjrsSedQ\&hl=cs\& sa=X\&ved=2ahUKEwjZmLz21MXnAhWC2-AKHS3WDW4Q6AEwAXoECAoQAQ\#v=onepage\&q=lyra\&f=false>.

RUBSAMEN, Walter H. The international 'catholic' repertoire of a Lutheran church in Nürnberg 15741597. Neuilly-sur-Seine: Société de musique d'autrefois, 1957.

STARKE, Reinhold. Johannes Nux (Nucis oder Nucius). Monatshefte für Musik-Geschichte. Leipzig: Breitkopf \& Härtel, 1904, 36. Jahrgang, no. 12, pp. 195-209.

THAMM, Jospeh. Musicalische Chronik der Stadt Neisse. Dülmen: Laumannsche Verlagsbuchhandlung, 1974.

ZYWIETZ, Michael. Nucius, Nux, Nucis, Johannes [online] In Die Musik in Geschichte und Gegenwart Allgemeine Enzyklopädie der Musik. 2016. [cit. 01.27. 2020] Access from: 〈https://www. mgg-online.com/article?id=mgg09561\&v=1.0\&rs=mgg09561\&q=nucius $>$. 
